\title{
Empowering the Cadre of Pregnant Women Control Program to Prevent
} Anemia

\author{
Levi Tina Sari ${ }^{1}$, Nevy Norma Renityas ${ }^{2}$, Ita Noviasari ${ }^{3}$
}

${ }_{1,2,3}$ Midwifery Department, STIKes Patria Husada Blitar, Indonesia

\section{Article Information}

History Article:

Received, 05/04/2021

Accepted, 02/05/2021

Published, 05/05/2021

\section{Keywords:}

Anemia, Cadre, Pregnant Women

\begin{abstract}
Anemia in pregnant women was one of the national health problems and has the potential to be dangerous for the fetus and pregnant women. So, the role of cadres was needed as the front line for early detection or screening in the community. The method used the provision of material with lectures and discussions, the gathered of cadres used a health protocol, where the provision of material lasts for 2 hours. As a result, it was known that there had been a change in knowledged and attituded of caregivers in the prevention and management of pregnant women related to anemia, and it was known that cadres who did not work would play an active roled in posyandu activities. Therefore, it was expected that Posyandu cadres will received seminars or trained in accordance with their respective fields. So that the implementation of health serviced in the community could be optimal.
\end{abstract}




\section{INTRODUCTION}

Anemia occurs due to a low number of red blood cells <11gr\% (OMS Organización Mundial de la Salud, 2011). One third of the world's population has anemia at $32.9 \%$, and the population group with the greatest risk of anemia is pregnant women 46\% in 2016 (Chaparro and Suchdev, 2019). In 2019 in the SSEA (South and Southeast Asia) countries around 54.1\% had mild anemia, $42.5 \%$ moderate anemia, $3.4 \%$ severe anemia (Gardner and Kassebaum, 2020). Indonesia in 2018 anemia sufferers in pregnant women was $48.9 \%$ (BPS, 2018).

he results showed that anemia in pregnancy can cause preeclampsia (Taner et al., 2015) added that anemia in pregnant women can increase the risk of preterm birth, maternal and child mortality, and infectious diseases. Iron deficiency anemia in the mother can affect the growth and development of the fetus / baby during pregnancy and after. The results of the 2018 Riskesdas stated that in Indonesia, $48.9 \%$ of pregnant women had anemia. As much as $84.6 \%$ anemia in pregnant women occurs in the 15-24 year age group (Kemenkes RI, 2019). Anemia is a national health problem and a potentially dangerous one for pregnant women and the fetus (Leny, 2019)

Lack of public understanding of anemia in pregnant women is a problem in providing support to anemia clients in pregnant women. Even though there has been counseling about anemia in pregnant women, it has not been fully socialized to health cadres and the community. Therefore, it requires the attention of various parties related to health services on the front lines, one of which is the cadres of pregnant women control program. Cadres of pregnant women control program is the implementer of the posyandu program to improve the health of mothers and children, the function of the posyandu's role is a hope in achieving a better degree of community welfare. There are around 45 cadres of pregnant women control program in Tegalan Village, Kandat District, Kediri Regency. The located village $10 \mathrm{KM}$ from the city center of Kediri. However, there are still many cases of anemia in pregnant women, this is due to the economic condition and lack of knowledge of pregnant women about anemia.

The role of cadres pregnant women control program to assist village midwives to be able to detect early health in pregnant women so that they are able to monitor pregnant women and deliver to the delivery of mothers who are safe and babies born healthy. The role of cadres is to recognize and detect risk factors early through measurement of upper arm circumference, measurement of hemoglobin $(\mathrm{Hb})$ levels and detection of four too many in pregnant women. Cadres of pregnant women control program are part of the community itself so that they can help improve the health status of pregnant women from a promotive and preventive side. Where's, the cadres of pregnant women control program can provide motivation and education to pregnant women for routine checks. The cadres of pregnant women control program will be able to provide motivation or even education for high-risk pregnant women to routinely carry out routine pregnancy checks. For this reason, it is necessary to carry out a training on simple prenatal examinations that can equip cadres in an effort to screen anemia

\section{METHOD}

Community service was carried out in 1 hamlet cadre, Tegalan village, Kandat district, Kediri district on August 29, 2020, this activity took place once. The schedule of activities is as follows :

1. A service team consisting of 3 lecturers and 3 students looking for a serviced location. Then the community service team together with the regional head and cadre heads planned a service with a social distanced system. 
2. Preparation for service activities, namely by prepared equipment and equipment needed for service activities consisted of minimum standard equipment, include: handsanitizer, mask, LCD and laptop.

3. The activity is carried out by distributed knowledge questionnaires about anemia in pregnant women and attitude questionnaires about the prevention and management of anemia in pregnant women.

4. Provided education about anemia to pregnant women and anemia screening, at this stage the provision of education is limited to 1 hour because it is to avoid transmission of covid.

5. Provided a postest to find out the knowledge and attitudes of the cadres after being given education.

\section{RESULT}

There are 12 cadres of pregnant women control program present at the village hall who specifically handle pregnant women in the pregnant women class program in Tegalan village. the activity lasts for 2 hours, and uses health protocols, namely used a hand sanitizer, mask and social distanced.

Table. 1 Numerical Results of Respondents' Knowledge about Anemia at Tegalan village $2020(n=12)$

\begin{tabular}{ccccc}
\hline Characteristics & \multicolumn{2}{c}{ Before } & \multicolumn{2}{c}{ After } \\
\hline Good & $\sum$ & $\%$ & $\sum$ & $\%$ \\
Sufficient & 5 & 42 & 12 & 100 \\
Less & 7 & 58 & 0 & 0 \\
Total & 0 & 0 & 0 & 0 \\
\hline
\end{tabular}

From the data above, it shows that the knowledged prior to the provision of material was about 7 cadres who had sufficient knowledged, and 5 cadres who had good knowledge. Then after giving the material it was known that $100 \%$ of the cadres had good knowledge about anemia.

Table 2. Numerical Results of
Respondents' Attitudes in Prevention and Management of Anemia in Pregnant Women at Tegalan Village $2020(n=12)$

\begin{tabular}{ccccc}
\hline Characteristics & \multicolumn{2}{c}{ Before } & \multicolumn{2}{c}{ After } \\
\hline & $\sum$ & $\%$ & $\sum$ & $\%$ \\
Positive & 4 & 33 & 12 & 100 \\
Negative & 8 & 67 & 0 & 0 \\
Total & 12 & 100 & 12 & 100 \\
\hline
\end{tabular}

From the table above showed that the attituded of the cadres before being given material on prevention and handled of anemia in pregnancy was 7 cadres who had negative attituded. Then the attituded of the cadres after being given the material was about $100 \%$ of the cadres had a positive attituded.

\section{DISCUSSION}

Cadre empowerment activities take place in an orderly manner and in accordance with health protocols, namely used masks, hand sanitizers and social distanced, the core event (given theory) lasts 1 hour. This activity received support from the head of the Tegalan village PKK, and cadres who specifically handle pregnant women.

Prior knowledge was given to 7 cadres who had sufficient knowledged, this was due to the lack of trained or seminary. Then, the provision of theory on prevention and management of anemia was carried out so that $100 \%$ of the cadres had good knowledged. The increased in cadres' knowledge was increased due to used the lecture and discussion method. From the results of the service's observations, the cadres were interested in the material and enthusiastic. That was confirmed by research from Lubis, that the increased in knowledge is caused by the information obtained replaces the previously acquired knowledge so as to improve the previous information. (Lubis, 2015). Therefore, the government, especially the village level government, held a seminar to increased knowledge of the cadre.

Most of the posyandu cadres, 
especially those who handle pregnant women who did not worked so they could have more time to do the pregnan women of control program activities, even attended seminars to increased cadre knowledged. That was in line with the opinion of Suhat and Hasananh that if the increased in knowledged of cadres was related to work, cadres who did not worked would have free time to carry out the pregnant women of control program activities. (Suhat and Hasanah, 2014). So, the goverment side have to collaborated with the local community health centers were required to be more selective in selected cadres, so that health programs could be carried out optimally.

Based on table 2, it shows that the cadres had a positive attitude as many as 4 cadres before giving the material, this is related to knowledge, if the respondent's knowledge is sufficient or insufficient, the attituded shows negative, that was supported by Suhat and Hasanah that one of the factors of cadres shows a negative attituded which was influenced by a less of knowledge. (Suhat and Hasanah, 2014). The knowledge possessed by cadres was one of the triggered factors that can influence changed in attituded in the pregnant women of control program.(Pakasi, Korah and Imbar, 2016). Therefore, the activeness of cadre in provided health information to pregnant women would affected the health of pregnant women.

After being given material on the prevention and management of anemia in pregnant women, the respondent's attituded showed that $100 \%$ had a positive attituded, this was influenced by several factors, the first was the leaflet. Leaflets were given before the event was given, and the process of provided material was with the discussion method, where participants read the leaflets for discussion material. The second factor is the entry of information that has been received by previous participants. The source of information that has been received previously and the time it was last received of this information did not affect the increase in knowledge and attitudes in the two groups (Mirzanie, Prawitasari and Widad, 2019). Interactive and interested discussions will created a good impression so that participants could easily received the information conveyed, as well as the distribution of leaflets, leaflets they could read at any time if they forgeted the health informastion.

\section{CONCLUSION}

Empowerment of cadres pregnant women of control program through counselled with interactive lecture and discussion methods, and the provision of leaflets could provided changes in cadres' knowledged and attituded in prevented and managed anemia in pregnant women. Cadres who did not worked would play an active role in pregnan women of control program activities.

\section{SUGESTION}

It was expected that cadres of pregnant women of control program would received seminars or trained periodically accorded to their respective fields. So that the implementation of health services in the community could be optimal.

\section{REFERENCES}

Badan Pusat Statistik. 2018. Prevalensi Pada Ibu Hamil. https://www.bps.go.id/indikator/indi kator/view_data/0000/data/1333/sdg s_2/1

Chaparro, C. M. and Suchdev, P. S. (2019) 'Anemia epidemiology, pathophysiology, and etiology in low- and middle-income countries', Annals of the New York Academy of Sciences, 1450(1), pp. 15-31. doi: 10.1111/nyas. 14092 .

Gardner, W. and Kassebaum, N. (2020) 'Global, Regional, and National Prevalence of Anemia and Its Causes 
in 204 Countries and Territories, 1990-2019', Current Developments in Nutrition, 4(Supplement_2), pp. 830-830. doi: 10.1093/cdn/nzaa053_035.

Kemenkes RI (2019) Profil Kesehatan Indonesia Tahun 2019, Kementrian Kesehatan Repoblik Indonesia.

Leny (2019) '1035325 Faktor-faktor yang Berhubungan dengan Kejadian Anemia Pada Ibu Hamil', Jurnal Kebidanan: Jurnal Medical Science Ilmu Kesehatan Akademi Kebidanan Budi Mulia Palembang, 9(2), pp. 161-167. doi: 10.35325/kebidanan.v9i2.195.

Lubis, Z. (2015) 'Pengetahuan Dan Tindakan Kader Posyandu Dalam Pemantauan Pertumbuhan Anak Balita', Jurnal Kesehatan Masyarakat, 11(1), p. 65 . doi: 10.15294/kemas.v11i1.3473.

Mirzanie, H., Prawitasari, S. and Widad, S. (2019) 'Pengaruh Metode Promosi Kesehatan Terhadap Pengetahuan dan Sikap Kader tentang Deteksi Dini Kanker Leher Rahim', Jurnal Kesehatan Reproduksi, 6(1), p. 19. doi: 10.22146/jkr.42373.

OMS Organización Mundial de la Salud (2011) 'The global prevalence of anaemia in 2011', Who, pp. 1-48. Available at: https://apps.who.int/iris/handle/1066 5/177094.

Pakasi, A., Korah, B. and Imbar, H. (2016) 'Hubungan Pengetahuan Dan Sikap Kader Kesehatan Dengan Pelayanan Posyandu', Jurnal Ilmiah Bidan, 4(1), p. 92118.

Suhat and Hasanah, R. (2014) 'Factors related to the activity of cadres in integrated health care sessions (study in Palasari health care district of Subang)', Kesehatan Masyarakat, 10(1), pp. 73-79.

Taner, C. E. et al. (2015) 'Prevalence and risk factors of anemia among pregnant women attending a highvolume tertiary care center for delivery', Journal of the Turkish German Gynecology Association, 16(4), pp. 231-236. doi: 10.5152/jtgga.2015.15071. 